\title{
A stable neurotensin-based radiopharmaceutical for targeted imaging and therapy of neurotensin receptor-positive tumours
}

\author{
Elisa García-Garayoa • Peter Bläuenstein • \\ Alain Blanc • Veronique Maes • Dirk Tourwé • \\ P. August Schubiger
}

Received: 3 June 2008 / Accepted: 11 July 2008 / Published online: 9 August 2008

(C) Springer-Verlag 2008

\begin{abstract}
Purpose Neurotensin (NT) and its high affinity receptor (NTR1) are involved in several neoplastic processes. Thus, NT-based radiopharmaceuticals are potential tracers for targeted diagnosis and therapy of NTR-positive tumours. A new analogue based on NT(8-13), NT-XIX, with the three enzymatic cleavage sites stabilised, was synthesised and tested.

Methods The synthesis was performed by Boc strategy. Labelling with ${ }^{99 \mathrm{~m}} \mathrm{Tc} /{ }^{188} \mathrm{Re}$ was performed using the tricarbonyl technique. Metabolic stability was tested in vitro and in vivo. NT-XIX was further characterised in vitro in HT-29 cells and in vivo in nude mice with HT-29 xenografts.

Results NT-XIX showed much longer half-lives than nonstabilised analogues. Binding to NTR1 was highly specific, although the affinity was lower than that of natural NT. Bound activity rapidly internalised into HT-29 cells and 50\% remained trapped after $24 \mathrm{~h}$. In the time-course biodistribution, the highest uptake was found in the tumour at all
\end{abstract}

This work was partly funded by the Fund for Scientific ResearchFlanders (Belgium), contract No. G.0036.04.

E. García-Garayoa $(\bowtie) \cdot$ P. Bläuenstein · A. Blanc $\cdot$

P. A. Schubiger

Paul Scherrer Institute, Center for Radiopharmaceutical Science, CH-5232 Villigen PSI, Switzerland

e-mail: elisa.garcia@psi.ch

V. Maes $\cdot$ D. Tourwé

Department of Organic Chemistry, Vrije Universiteit Brussels,

Pleinlaan 2,

1050 Brussels, Belgium

P. A. Schubiger

Institute of Pharmaceutical Sciences, ETH Zurich,

Wolfgang-Pauli Strasse 10,

CH-8093 Zurich, Switzerland p.i. times. In vivo uptake was specific, and accumulation of activity in the kidneys was low. Radioactivity clearance from healthy organs was faster than that from the tumour, resulting in improved tumour-to-tissue ratios and good SPECT/CT imaging. Treatment with ${ }^{188} \mathrm{Re}-\mathrm{NT}$-XIX (30 MBq, in three or four fractions) decreased tumour growth by $50 \%$ after 3 weeks.

Conclusion The high in vivo stability and the favourable in vivo behaviour makes NT-XIX an excellent candidate for the imaging and therapy of NTR1-positive tumours.

Keywords Neurotensin analogue · Tumour imaging · SPECT/CT Peptide receptor radionuclide therapy .

${ }^{188} \mathrm{Re} \cdot{ }^{99 \mathrm{~m}} \mathrm{Tc} \cdot$ Radiolabelled peptides $\cdot$ Therapy (peptides) $\cdot$ Endocrinology $\cdot$ Oncology

\section{Introduction}

Neuropeptide-based radiopharmaceuticals are interesting compounds for tumour localisation and therapy, as has been demonstrated with radiolabelled somatostatin (sst) analogues for sst-receptor-positive tumours [1,2]. Many tumours lack sst receptors but over-express other neuropeptide receptors, which have therefore become potential targets. This is the case with neurotensin (NT) and NT receptors (NTR), which have been associated with neoplastic progression of human cancers such as lung, pancreatic, colon, prostate and breast cancers [3-4].

NT is a tridecapeptide originally isolated from calf hypothalamus [5]. It fulfils a dual function: neurotransmitter or neuromodulator in the nervous system and local hormone in the periphery [6,7]. Three NTR subtypes have been described [8]. NTR1 and NTR2 are G-protein-coupled 
receptors, whereas NTR3 is a single trans-membrane domain type I receptor, showing homology with sortilin [9]. Most NT actions at the central and peripheral levels are mediated by NTR1. The role of NTR2 is still controversial, and little is known regarding the physiological functions of NTR3. Localisation of NTR3 is predominantly intracellular in close proximity to the nucleus and seems to be involved in the internalisation and trafficking of NT [10]. High overexpression of NTR1 has been found in several human tumours $[3,4]$. For example, NTR1 incidences of $75-88 \%$ and $91 \%$ have been reported for exocrine pancreatic carcinoma [11, 12] and invasive ductal breast cancer [13], respectively. The high expression of NT receptors found in exocrine pancreatic cancers is of special interest. Whereas significant progress has been made in the management of many other forms of cancer, pancreatic cancer remains an enigma and continues to be highly prevalent in western countries, where it is the fifth leading cause of death from cancer [14]. The vast majority of pancreatic cancers are diagnosed at an advanced stage, when the tumours are no longer resectable and metastasis has already occurred. Souazé et al. [13] recently reported on the role of NT and NT receptors in breast cancer progression. Expression of NTR in breast cancers is an early event, which is involved in neoplastic transformation. Breast cancer is the most common form of cancer in females and, despite the decline in breast cancer deaths in the last decades, is still the second most fatal cancer in women after lung cancer [15]. The development of new early diagnostic assays and novel therapeutic modalities could have a major impact on the treatment of these cancers. Over-expressed NTR could be targeted with radiolabelled NT analogues and would offer an interesting tool for tumour imaging and subsequent therapeutic intervention. The main drawback of natural NT is its rapid degradation in plasma. The three cleavage sites in the metabolic deactivation of $\mathrm{NT}(8-13)$ are $\mathrm{Arg}^{8}-\mathrm{Arg}^{9}$, Pro $^{10}-$ Tyr $^{11}$ and Tyr $^{11}-\mathrm{Ile}^{12}$ [16]. Modification of $\mathrm{Arg}^{8}-\mathrm{Arg}^{9}$ and $\mathrm{Tyr}^{11}-\mathrm{Ile}^{12}$ led to increased plasma stability, high affinity for NTR1 and also good in vivo tumour uptake [17-19]. With one analogue (NT-XI), visualisation of the tumour of a patient with ductal pancreatic adenocarcinoma was possible, which demonstrates the potential utility of NT analogues for imaging of these tumours [20].

$\mathrm{Tc}$ and Re are transition metals of the same group of the periodic table and, thus, share similar chemical properties. In low oxidation states, the organometallic precursor $f a c$ $\left[M(\mathrm{CO})_{3}\left(\mathrm{H}_{2} \mathrm{O}\right)_{3}\right]^{+}$core $(M=\mathrm{Tc}, \mathrm{Re})$ forms stable complexes that are small and kinetically inert. Therefore, $\mathrm{Tc}(\mathrm{I}) / \operatorname{Re}(\mathrm{I})$ represent an attractive pair to label low molecular weight molecules for diagnostic imaging and targeted radiotherapy. ${ }^{99 \mathrm{~m}} \mathrm{Tc}$ shows ideal physical properties (half-life $=6.02 \mathrm{~h}$; $\gamma$-emission energy $=140 \mathrm{keV}, 89 \%$ ) for diagnostic imaging, and ${ }^{188} \mathrm{Re}$ has favourable decay properties (half-life= $17.0 \mathrm{~h} ; \beta$-emission energy $=2.12 \mathrm{MeV} ; \gamma$-emission energy $=$ $155 \mathrm{keV}, 15 \%$ ) for potential therapeutic application.

\section{Materials and methods}

\section{Synthesis of NT-XIX and radiolabelling}

Peptide solid-phase synthesis was carried out on a Merrifield resin, using a semi-automatic Labortec Peptide Synthesizer SP640B. ( $\left.N^{\alpha} \mathrm{His}\right) \mathrm{Ac}$ (retro[ $N^{\alpha}$-carboxymethyl-histidine]) was coupled to the $\mathrm{N}$-terminus as a ligand for labelling with ${ }^{99 \mathrm{~m}} \mathrm{Tc}$ and ${ }^{188} \mathrm{Re}$. The synthesis of NT-XIX (Table 1) was performed as described in detail by Maes et al. [21]. Radiolabelling with ${ }^{99 \mathrm{~m}} \mathrm{Tc}\left({ }^{99} \mathrm{Mo} /{ }^{99 \mathrm{~m}} \mathrm{Tc}\right.$ generator, Mallinckrodt, Petten, The Netherlands) was performed as recently described $[22,23]$. Briefly, 1 to $10 \mathrm{GBq} / \mathrm{mL}$ pertechnetate was added to the mixture of sodium boranocarbonate, borax, potassium-sodium tartrate tetrahydrate and sodium carbonate and heated for $20 \mathrm{~min}$ at $100^{\circ} \mathrm{C}$. The solution was cooled and neutralised $(\mathrm{pH}$ 6.5). This solution

Table 1 Stability and affinity of different radiolabelled NT analogues

\begin{tabular}{|c|c|c|c|c|c|}
\hline \multirow[t]{3}{*}{ Analogue } & \multirow[t]{3}{*}{ Amino acid sequence } & \multicolumn{3}{|c|}{ Metabolic stability $\left(t_{1 / 2}\right)$} & \multirow{3}{*}{$\begin{array}{l}\text { Affinity } \\
K_{\mathrm{d}}(\mathrm{nmol} / \mathrm{L})\end{array}$} \\
\hline & & \multicolumn{2}{|l|}{ In vitro } & \multirow{2}{*}{$\begin{array}{l}\text { In vivo } \\
\text { Blood }\end{array}$} & \\
\hline & & Human plasma & HT-29 cells & & \\
\hline${ }^{99 \mathrm{~m}} \mathrm{Tc}-\mathrm{NT}-\mathrm{II}^{\mathrm{a}}$ & $\left(N^{\alpha} H i s\right) A c$-Arg-Arg-Pro-Tyr-Ile-Leu & $5.6 \mathrm{~min}$ & n.d. & $<1 \min$ & $0.3 \pm 0.2$ \\
\hline${ }^{99 m}$ Tc-NT-X ${ }^{\mathrm{a}}$ & $\left(N^{\alpha} H i s\right) A c-$ Arg-Arg -Pro-Tyr-Tle-Leu & $4 \mathrm{~h}$ & $2 \mathrm{~h}$ & n.d. & $0.2 \pm 0.1$ \\
\hline${ }^{99 \mathrm{~m}} \mathrm{Tc}_{\mathrm{c}} \mathrm{NT}-\mathrm{VIII}{ }^{\mathrm{a}}$ & $\left(N^{\alpha} H i s\right) A c-\left(\mathbf{N}-\mathbf{C H}_{\mathbf{3}}\right)$-Arg-Lys-Pro-Tyr-Tle-Leu & 20 days & $4.2 \mathrm{~h}$ & n.d. & $1.8 \pm 0.9$ \\
\hline${ }^{99 \mathrm{~m}}$ Tc-NT-XI ${ }^{\mathrm{a}}$ & $\left(N^{\alpha} H i s\right) A c-L y s-\Psi\left(\mathbf{C H}_{2} \mathbf{N H}\right)$-Arg-Pro-Tyr-Tle-Leu & 21 days & $4.5 \mathrm{~h}$ & n.d. & $0.5 \pm 0.3$ \\
\hline${ }^{99 \mathrm{~m}} \mathrm{Tc}-\mathrm{NT}-\mathrm{XII}{ }^{\mathrm{a}}$ & $\left(N^{\alpha} H i s\right) A c-A r g-\left(\mathbf{N}-\mathbf{C H}_{\mathbf{3}}\right)$-Arg -Pro-Tyr-Tle-Leu & 21 days & $6.5 \mathrm{~h}$ & $0.75 \mathrm{~h}$ & $2.0 \pm 1.6$ \\
\hline${ }^{99 \mathrm{~m}} \mathrm{Tc}-\mathrm{NT}-\mathrm{XIX}$ & (N $\left.{ }^{\alpha} H i s\right) A c-A r g-\left(\mathbf{N}-\mathbf{C H}_{\mathbf{3}}\right)$-Arg-Pro-Dmt-Tle-Leu & 28 days & 2.4 days & $1.4 \mathrm{~h}$ & $15.0 \pm 9.2$ \\
\hline
\end{tabular}

The modifications in the binding sequence are marked in bold.

( $N^{\alpha}$ His)Ac Retro[ $N^{\alpha}$-carboxymethyl-histidine], Tle tertiary-leucine, Dmt dimethyltyrosine, n.d. not determined

${ }^{\text {a }}$ Previously published, for comparison [17-19, 23] 
was mixed with the NT-XIX analogue $(0.02 \mu \mathrm{mol})$ and heated at $75^{\circ} \mathrm{C}$ for $1 \mathrm{~h}$. The final product was analysed and purified with high-performance liquid chromatography (HPLC) to eliminate the excess of free peptide and other impurities.

Radiolabelling with ${ }^{188} \mathrm{Re}\left({ }^{188} \mathrm{~W} /{ }^{188} \mathrm{Re}\right.$ generator, Oak Ridge National Laboratories, USA) was performed as follows: $7.5 \mathrm{mg} \mathrm{NH} \mathrm{NH}_{3}(0.25 \mathrm{mmol})$ in a closed $10 \mathrm{~mL}$ penicillin vial were filled with a $\mathrm{CO}$ flow $(2 \mathrm{~mL} / \mathrm{min}$ for $10 \mathrm{~min})$. In a second vial, $20 \mu 11 \mathrm{mmol} / \mathrm{L}$ peptide solution was mixed with $60 \mu \mathrm{L} 4 \mathrm{M} \mathrm{HCl}, 0.25 \mathrm{~mL} 0.5 \mathrm{M} \mathrm{2-}(N-$ morpholino)ethanesulfonic acid (MES), $5 \mathrm{mg}$ sodium ascorbate and $1 \mathrm{~mL}$ generator eluate (perrhenate, $50 \mathrm{MBq}$ to $0.5 \mathrm{GBq} / \mathrm{mL}$ ). This solution was purged with argon (10 $\mathrm{mL} / \mathrm{min}$ for $2 \mathrm{~min}$ ), then transferred to the vial with the reducing agent and heated at $75-80^{\circ} \mathrm{C}$ for $4 \mathrm{~h}$. The $\mathrm{pH}$ was 6.5 to 7 . The final product was purified with HPLC.

\section{Cell culture}

The human colon adenocarcinoma HT-29 cells, from which the human NT1 receptor was originally cloned [24], were used. HT-29 cells were obtained from the European Collection of Cell Culture (ECACC, Salisbury, England, UK). Cells were maintained in McCoy's 5A-GLUTAMAX I supplemented with $10 \%$ FCS, $100 \mathrm{IU} / \mathrm{mL}$ penicillin, $100 \mu \mathrm{g} / \mathrm{mL}$ streptomycin and $0.25 \mu \mathrm{g} / \mathrm{mL}$ amphotericin B (Invitrogen AG, Basel, Switzerland). Cells were cultured at $37^{\circ} \mathrm{C}$ in a humidified incubator under an atmosphere containing $5 \% \mathrm{CO}_{2}$ and subcultured weekly.

In vitro metabolic stability

In vitro stability was analysed in human plasma and HT-29 cells as previously described [17]. Plasma samples were incubated at $37^{\circ} \mathrm{C}$ with ${ }^{99 \mathrm{~m}} \mathrm{Tc}-\mathrm{NT}-\mathrm{XIX} 0.2 \mathrm{pmol} / \mathrm{mL}$ for different times (up to $24 \mathrm{~h}$ ). After incubation, proteins were precipitated by mixing $0.25 \mathrm{~mL}$ of plasma sample with $0.75 \mathrm{~mL}$ of ethanol/acetonitrile (1:1), and the mixture centrifuged at $14,000 \times \mathrm{g}$ for $10 \mathrm{~min}$. The supernatant was filtered and analysed by HPLC using a Nucleosil ${ }^{\circledR} 100-5$ $\mathrm{C}_{18}$ column (Macherey-Nagel, Oensingen, Switzerland) and equipped with a radioactivity detector (Radiomatic Model 525TR). The percentage of intact peptide was determined from the radioactivity chromatograms, in which the peaks of intact peptide and the different degradation products were represented. For studies of degradation in cells, intact HT-29 cells $\left(2 \times 10^{6}\right.$ cells $\left./ \mathrm{mL}\right)$ were incubated at $37^{\circ} \mathrm{C}$ with ${ }^{99 \mathrm{~m}}$ Tc-NT-XIX $0.2 \mathrm{pmol} / \mathrm{mL}$ for different times (up to $24 \mathrm{~h}$ ). After incubation, cells were lysed with an ultrasound probe (Skan) at $4{ }^{\circ} \mathrm{C}$ (duty cycle: 40; output control: 4; $4 \mathrm{~min}$ ), proteins were precipitated with ethanol/acetonitrile $(1: 1)$ and the suspension was filtered. A sample of the filtrate was analysed by HPLC as above.
In vivo metabolic stability

In vivo stability was analysed in Balb/c mice. Animals were injected i.v. with ${ }^{99 m}$ Tc-NT-XIX (25 MBq). At 1 - and 2-h post-injection (p.i.), mice were sacrificed, and blood, urine, kidney and liver were collected and kept in ice. Liver and kidney were suspended in phosphate-buffered saline (PBS) with $1 \%$ Triton X-100 and homogenised. All the samples were then centrifuged at $14,000 \times g$ for $5 \mathrm{~min}$. The supernatant of each sample was collected in tubes, and the pellets were resuspended in PBS and centrifuged again. The final supernatants were collected in the corresponding tubes. Proteins were precipitated with ethanol/acetonitrile (1:1) and centrifuged at $14,000 \times \mathrm{g}$ for $10 \mathrm{~min}$, the pellet was discarded and the supernatant was filtered. A sample of the filtrate was analysed by HPLC as above.

Binding assays

Binding assays were performed with HT-29 cells at confluence as already described [20, 22]. For saturation studies, cells were incubated in triplicate with increasing concentrations $(0.3-30 \mathrm{nmol} / \mathrm{L})$ of purified ${ }^{99 \mathrm{~m}} \mathrm{Tc}-\mathrm{NT}-\mathrm{XIX}$ for $1 \mathrm{~h}$ at $37^{\circ} \mathrm{C}$. After washing with PBS to eliminate unbound activity, cells were lysed with $1 \mathrm{~N} \mathrm{NaOH}$ at $37^{\circ} \mathrm{C}$. Bound radioactivity was measured in a $\gamma$-counter (Packard Canberra Cobra II Auto-Gamma counter, Meriden, USA). Non-specific binding was determined with $1 \mu \mathrm{mol} / \mathrm{L}$ unlabelled NT(8-13).

Internalisation/efflux

Internalisation studies were performed as previously described [17, 19], with HT-29 cells at confluence. Internalisation of ${ }^{99 \mathrm{~m}}$ Tc-NT-XIX $(10 \mathrm{kBq})$ was evaluated at $37^{\circ} \mathrm{C}$ up to $2 \mathrm{~h}$. Surface bound activity was removed by acid wash $(50 \mathrm{mmol} / \mathrm{L}$ glycine- $\mathrm{HCl} / 100 \mathrm{mmol} / \mathrm{L} \mathrm{NaCl}$, $\mathrm{pH}$ 2.8) at room temperature, and internalised peptide was recovered with $1 \mathrm{~N} \mathrm{NaOH}$. Non-specific internalisation was determined in the presence of $1 \mu \mathrm{mol} / \mathrm{L} \mathrm{NT(8-13).} \mathrm{Results}$ are expressed as a percentage of the maximal activity associated with the cells (surface bound + internalised) and as a percentage of internalised activity in relation to the total activity added.

For efflux experiments, confluent cells in 6-cm Petri dishes were incubated at $37^{\circ} \mathrm{C}$, with ${ }^{99 m}$ Tc-NT-XIX (10 kBq) for $1 \mathrm{~h}$ to allow maximal internalisation. Then, the medium was discarded, and the cells were washed with cold PBS. New medium was added, and the cells were incubated at $37^{\circ} \mathrm{C}$. At different times ( $30 \mathrm{~min}$ to $24 \mathrm{~h}$ ), the medium was collected. Membrane-bound activity was recovered by acid wash and internalised activity with $1 \mathrm{~N}$ $\mathrm{NaOH}$. Released analogue (activity in the medium), 
membrane-bound analogue and internalised analogue were measured by $\gamma$-counting. Results are expressed as the percentage of total activity at each time point.

\section{Biodistribution studies}

All animal experiments were conducted in compliance with the Swiss animal protection laws and the guidelines for scientific animal trials established by the Swiss Academy of Medical Sciences and the Swiss Academy of Natural Sciences. Female CD-1 Nu/Nu mice (6- to 8-week-old, Charles River, Sulzfeld, Germany) were inoculated with $5 \times$ $10^{6}$ HT-29 tumour cells in the left flank and in the shoulder. When tumours were palpable (10-12 days), mice received ${ }^{99 \mathrm{~m}}$ Tc-NT-XIX or ${ }^{188}$ Re-NT-XIX (3.5-4 MBq/mouse, peptide mass of approximately $0.5 \mathrm{ng}$ ) administered intravenously (i.v.). Animals were sacrificed by cervical dislocation at different p.i. times $(1.5,5$ and $24 \mathrm{~h}$; additionally at $48 \mathrm{~h}$ for ${ }^{188}$ Re-NT-XIX) and then dissected. Different organs and tissues were collected and weighed, and the radioactivity was determined by $\gamma$-counting. A minimum of three animals were used per time point. Results are expressed as a percentage of injected dose per gram of tissue $(\% \mathrm{ID} / \mathrm{g})$. In blockade experiments, mice received 3.5-4 MBq of ${ }^{99 \mathrm{~m}} \mathrm{Tc}-\mathrm{NT}-\mathrm{XIX}$ co-injected i.v. with $0.3 \mathrm{mg} /$ mouse of NT-XI administered intravenously, a doubly stabilised analogue of the same series with good affinity for NTR1 [18]. Animals were sacrificed at $1.5 \mathrm{~h}$ p.i., the different organs/tissues were removed and the radioactivity was measured in a $\gamma$-counter.

\section{SPECT/CT imaging}

Post-mortem studies were performed $1.5 \mathrm{~h}$ after i.v. injection of ${ }^{99 \mathrm{~m}}$ Tc-NT-XIX (3.5-4 MBq). Images were obtained on an X-SPECT ${ }^{\text {TM}}$-system (Gamma Medica, Northridge, USA) equipped with a single-head SPECT device and a CT device. SPECT data were acquired and reconstructed with the software LumaGEM. CT data were acquired by an $\mathrm{X}$-ray CT-system (Gamma Medica ${ }^{\mathrm{TM}}$ ) and reconstructed with the software Cobra. Fusion of SPECT and CT data was performed with the software IDL Virtual Machine ${ }^{\mathrm{TM}}$. Images were generated with the software Amira ${ }^{\mathrm{TM}}$.

\section{Preliminary therapy studies}

Therapy studies were conducted in mice with HT-29 xenografts. Animals were divided into four groups. The control group received i.v. the vehicle (saline) with no activity. Treated groups received i.v. ${ }^{188} \mathrm{Re}-\mathrm{NT}$-XIX $30 \mathrm{MBq} / \mathrm{mouse}$ in fractionated doses: 2 of $15 \mathrm{MBq}$ (at days 0 and 3), 3 of $10 \mathrm{MBq}$ (at days 0,3 and 6) and 4 of $7.5 \mathrm{MBq}$ (at days 0,3 , 6 and 9). The growth of the tumours was monitored for 3 weeks starting the day of the first injection (day 0). A calliper was used to measure the longest $(L)$ and the shortest $(W)$ dimensions of the tumours. The tumour was assumed as an ellipsoid, and its volume was calculated with the formula: $V_{t}=(\pi / 6) L W^{2}$. The relative volume of tumours, $V_{\mathrm{r}}$, was defined as $V_{\mathrm{r}}=V_{t} / V_{0}$, where $V_{t}$ was the measurement at time $t$ (days after the first injection), and $V_{0}$ was the measurement at day 0 (day of the first injection).

\section{Statistical analysis}

Differences between blocked and control groups in the biodistribution studies were analysed by Welch-corrected $t$ test (variances between the groups are significantly different). $p<0.01$ was considered statistically significant.

One-way ANOVA, followed by Tukey's comparison test, was used to analyse differences in the kidney, liver and tumour uptakes between the new stable NT analogue and previous doubly stabilised analogues. $p<0.01$ was considered statistically significant.

Differences in relative tumour volume were analysed by one-way ANOVA (Tukey's as post hoc test). $p<0.05$ was considered statistically significant.

\section{Results}

\section{Radiolabelling}

After labelling with ${ }^{99 \mathrm{~m}} \mathrm{Tc}$, the yield was higher than $95 \%$. In the HPLC chromatogram, the peak of ${ }^{99 \mathrm{~m}}$ Tc-NT-XIX appeared at a retention time of $17.1 \mathrm{~min}$ (Fig. 1a). Labelling with ${ }^{188} \mathrm{Re}$ resulted in lower yields, $75-80 \%$. The main peak in the HPLC chromatogram, with a retention time of 16.9 min, corresponded to ${ }^{188}$ Re-NT-XIX. The second peak, at a retention time of $3.5 \mathrm{~min}$, represented perrhenate (Fig. 1b). Both ${ }^{99 \mathrm{~m}}$ Tc-NT-XIX and ${ }^{188}$ Re-NT-XIX were purified by HPLC to eliminate the excess of cold peptide and other impurities. Perrhenate was not detectable in the HPLC of the purified ${ }^{188}$ Re-NT-XIX.

The chemical stability of ${ }^{188}$ Re-NT-XIX was tested in phosphate buffer up to $10 \mathrm{GBq}$. The complex was stable for at least $48 \mathrm{~h}$, and, after $72 \mathrm{~h}, 70 \%$ of the complex was still stable.

In vitro metabolic stability

The three changes introduced in NT-XIX conferred a high in vitro stability to the molecule. Most ${ }^{99 \mathrm{~m}}$ Tc-NT-XIX was still intact after $24 \mathrm{~h}$ at $37^{\circ} \mathrm{C}$. Plasma half-life estimated in 28 days was significantly improved compared to that of the non-stabilised analogue ${ }^{99 \mathrm{~m}}$ Tc-NT-II (only $5.6 \mathrm{~min}$ ) and similar to that of previous analogues $[17-19,23]$. Stability in HT-29 cells was also very high, and $70 \%$ of ${ }^{99 m}$ Tc-NT-XIX 
a

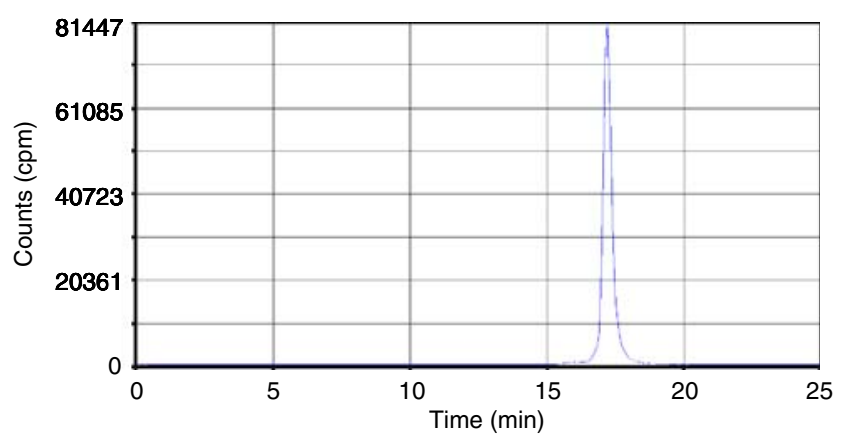

b

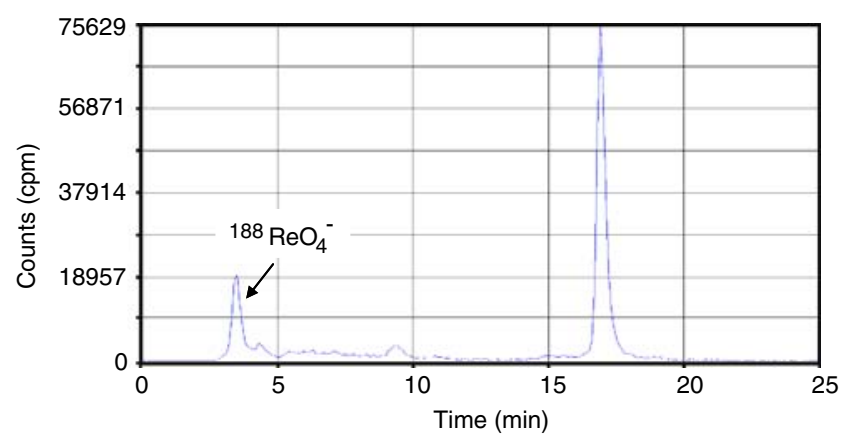

Fig. 1 Representative HPLC radiochromatograms after labelling. a ${ }^{99 m}$ Tc-NT-XIX. b ${ }^{188}$ Re-NT-XIX

was still intact after $24 \mathrm{~h}$ at $37^{\circ} \mathrm{C}$. The half-life in HT-29 cells was 2.4 days and was an important improvement compared to doubly stabilised analogues such as ${ }^{99 \mathrm{~m}} \mathrm{Tc}-\mathrm{NT}-\mathrm{XI}$ and ${ }^{99 \mathrm{~m}}$ Tc-NT-XII, for which the half-lives in tumour cells were not higher than $6.5 \mathrm{~h}$ [17-19]. Data are presented in Table 1.

In vivo metabolic stability

${ }^{99 m}$ Tc-NT-XIX was more rapidly metabolised in vivo than in vitro, with a half-life in blood of $1.4 \mathrm{~h}$ (Table 1). However, it was more stable than the doubly stabilised analogue ${ }^{99 \mathrm{~m}} \mathrm{Tc}-$ NT-XII (half-life of $45 \mathrm{~min}$ in vivo, Table 1) and much more stable than the unmodified analogue ${ }^{99 \mathrm{~m}}$ Tc-NT-II. Most ${ }^{99 \mathrm{~m}}$ Tc-NT-II was metabolised after 1 min (less than $9 \%$ was intact in blood at this time), whereas about $40 \%$ of ${ }^{99 \mathrm{~m}}$ Tc-NT-XII and more than $80 \%$ of ${ }^{99 \mathrm{~m}}$ Tc-NT-XIX remained intact after $1 \mathrm{~h}$.

\section{Binding assays}

Binding of ${ }^{99 \mathrm{~m}}$ Tc-NT-XIX to intact cells was saturable and highly specific. The affinity of ${ }^{99 \mathrm{~m}}$ Tc-NT-XIX remained at nanomolar level $\left(K_{\mathrm{d}}\right.$ of $\left.15.0 \mathrm{nmol} / \mathrm{L}\right)$, although it was lower than that obtained for ${ }^{125} \mathrm{I}-\mathrm{NT}(1.6 \mathrm{nmol} / \mathrm{L})$, the nonstabilised ${ }^{99 \mathrm{~m}}$ Tc-NT-II $(0.3 \mathrm{nmol} / \mathrm{L})$ and the stabilised
${ }^{99 \mathrm{~m}}$ Tc-NT-VIII $(1.8 \mathrm{nmol} / \mathrm{L}),{ }^{99 \mathrm{~m}} \mathrm{Tc}-\mathrm{NT}-X I(0.5 \mathrm{nmol} / \mathrm{L})$ or ${ }^{99 \mathrm{~m}}$ Tc-NT-XII $(2.0 \mathrm{nmol} / \mathrm{L})$. Results are summarised in Table 1.

Internalisation/efflux

After binding, rapid internalisation of the complex NT analogue-NTR1 has been reported [25]. Internalisation of ${ }^{99 \mathrm{~m}}$ Tc-NT-XIX into HT-29 cells was also rapid and time dependent. It sharply increased during the first $30 \mathrm{~min}$ with maximal internalisation rates of $90 \%$. It then reached a plateau and remained stable for at least $2 \mathrm{~h}$, with a pattern similar to other ${ }^{99 \mathrm{~m}}$ Tc-NT analogues (Fig. 2a). Internalisation related to the total activity added increased with time up to $5.5 \%$ after $2 \mathrm{~h}$. Other ${ }^{99 \mathrm{~m}} \mathrm{Tc}-\mathrm{NT}$ analogues exhibited higher internalisation rates, which may be ascribed to their higher affinity for the receptors. However, the less stable analogues also showed an important decrease
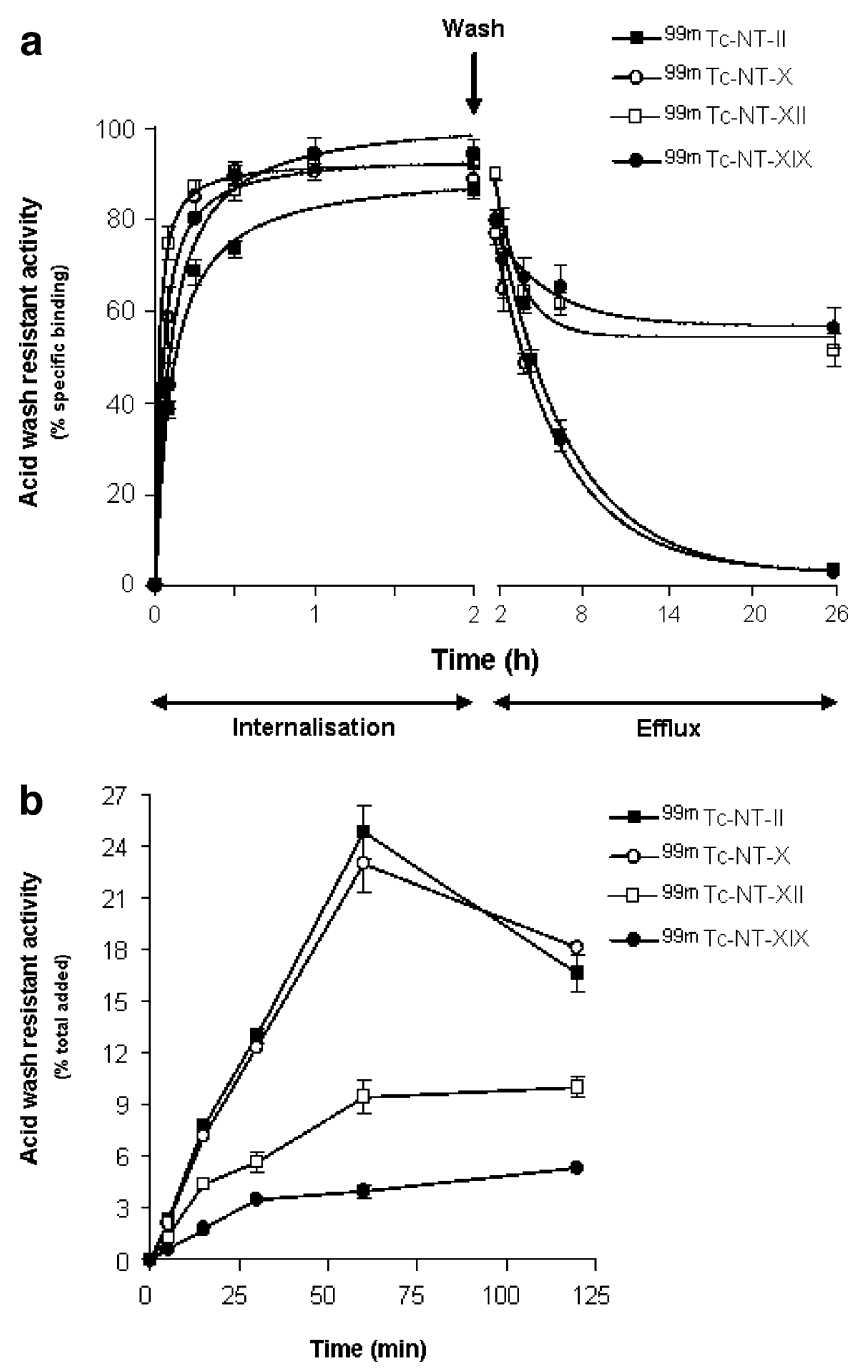

Fig. 2 Internalisation in HT-29 cells after incubation at $37^{\circ} \mathrm{C}$. a Internalisation/efflux related to the activity associated with the cells. b Internalisation related to total activity 
after $1 \mathrm{~h}$, likely due to a rapid degradation in the tumour cells. Results are depicted in Fig. 2 b.

Concerning the release of the activity after maximal internalisation, approximately $50 \%$ of the internalised activity remained inside the cells after $24 \mathrm{~h}$ at $37^{\circ} \mathrm{C}$ (Fig. 2a). Radioactivity retention in tumour cells was comparable to other doubly stabilised ${ }^{99 \mathrm{~m}} \mathrm{Tc}-\mathrm{NT}$ analogues of the same series [19] and much higher than that of the less stable analogue ${ }^{99 \mathrm{~m}} \mathrm{Tc}-\mathrm{NT}-\mathrm{X}$ or the non-stabilised ${ }^{99 \mathrm{~m}} \mathrm{Tc}$ NT-II (Fig. 2a).

\section{Biodistribution studies}

At $1.5 \mathrm{~h}$ p.i., uptake of ${ }^{99 \mathrm{~m}} \mathrm{Tc}-\mathrm{NT}$-XIX in most healthy organs was low. The highest uptake was found in the intestinal tract and in the tumour, $6.0 \pm 2.3 \%$ and $5.9 \pm 1.1 \%$
ID/g, respectively (Fig. 3a). Renal uptake, $3.6 \pm 1.0 \% \mathrm{ID} / \mathrm{g}$, was significantly lower than that found for previously reported analogues such as NT-VIII, NT-XI and NT-XII (10.3\%, $14.6 \%$ and $9.1 \% \mathrm{ID} / \mathrm{g}$, respectively; Fig. 4) [1719]. After $5 \mathrm{~h}$, a large amount of activity had cleared from most of the organs. Interestingly, tumour activity wash-out was lower than that of intestine, NTR-positive tissue. Thus, tumour uptake was the highest at $5 \mathrm{~h}$ p.i. (5.2 \pm $0.5 \% \mathrm{ID} / \mathrm{g}$ ), exceeding the $3.4 \pm 0.7 \% \mathrm{ID} / \mathrm{g}$ in intestine (Fig. 3a). At 24 h p.i., a similar biodistribution pattern was observed, with the highest uptake in the tumour $(2.5 \pm$ $0.2 \% \mathrm{ID} / \mathrm{g}$ ). Moreover, from 5 to $24 \mathrm{~h}$, a faster clearance of activity was found in the intestine compared to the tumour. Tumour-to-blood ratios at 1.5 and $5 \mathrm{~h}$ were similar to our previous NT analogues [17, 19]; however, at $24 \mathrm{~h}$, higher tumour-to-blood ratios were found for ${ }^{99 \mathrm{~m}}$ Tc-NT-XIX.
Fig. 3 Biodistribution in mice with HT-29 tumour xenografts. a Time-course biodistribution: ${ }^{99 \mathrm{~m}}$ Tc-NT-XIX vs. ${ }^{188}$ Re-NTXIX (3.5-4 MBq/mouse i.v. each). b Biodistribution at $1.5 \mathrm{~h}$ p.i.: unblocked vs. blocked. Blocked animals received ${ }^{99 \mathrm{~m}}$ Tc-NT-XIX co-injected with unlabelled NT-XI [18], $0.3 \mathrm{mg} /$ mouse. Data represent percentage of injected dose (ID) per gram of tissue (mean $\pm \mathrm{SD}$, 3-5 animals). $* p<0.01$ and $* * p<0.001$ vs unblocked group, Welch-corrected $t$ test
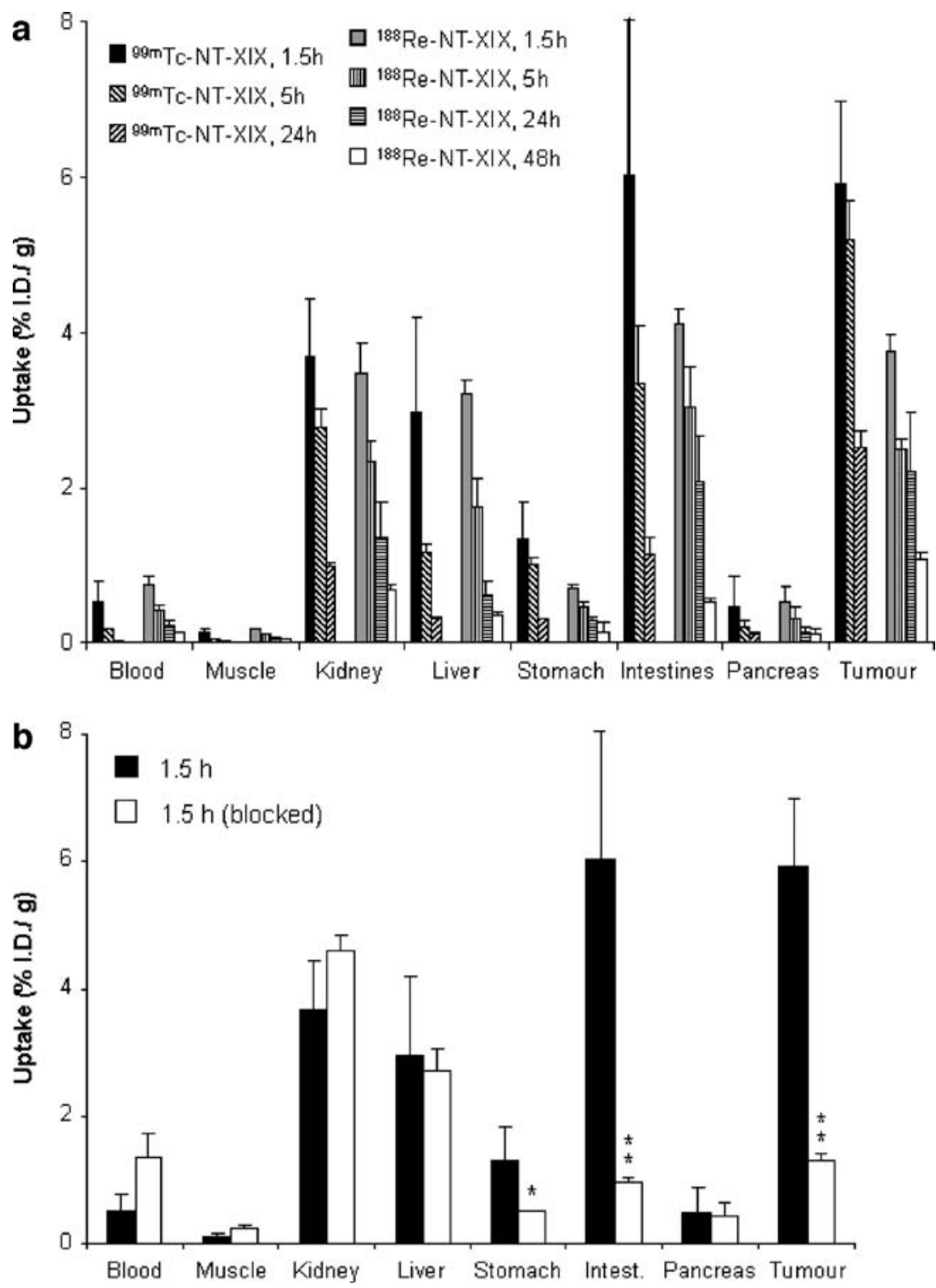


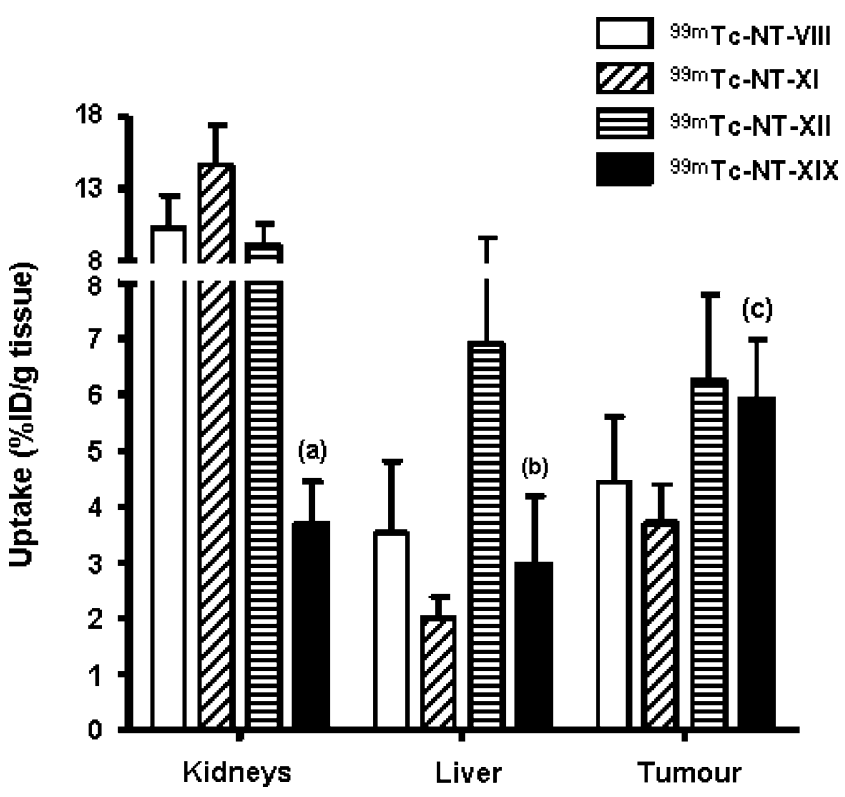

Fig. 4 Comparison of the uptake of stabilised ${ }^{99 \mathrm{~m}} \mathrm{Tc}-\mathrm{NT}$ analogues in kidney, liver and HT-29 tumour xenografts at $1.5 \mathrm{~h}$ p.i. The analogues ${ }^{99 \mathrm{~m}}$ Tc-NT-VIII, ${ }^{99 \mathrm{~m}} \mathrm{Tc}-\mathrm{NT}$-XI and ${ }^{99 \mathrm{~m}} \mathrm{Tc}-\mathrm{NT}$-XII have been previously reported [17-19]. Statistical analysis (one-way ANOVA+Tukey's post hoc test): (a) $p<0.001$ vs. ${ }^{99 \mathrm{~m}} \mathrm{Tc}-\mathrm{NT}-\mathrm{VIII},{ }^{99 \mathrm{~m}} \mathrm{Tc}-\mathrm{NT}-\mathrm{XI}$ and ${ }^{99 \mathrm{~m}} \mathrm{Tc}-$ NT-XII; (b) $p<0.001$ vs. ${ }^{99 \mathrm{~m}}$ Tc-NT-XII; (c) $p<0.01$ vs. ${ }^{99 \mathrm{~m}} \mathrm{Tc}-\mathrm{NT}-\mathrm{XI}$

Tumour-to-kidney and tumour-to-liver ratios (Table 2) were also significantly better for the new analogue at all p.i. times [17-19].

In blockade studies, a similar accumulation was found in most organs with the exception of the tumour, intestine and stomach (NTR1-positive tissues), in which the inhibition was statistically significant, $78 \%, 84 \%$ and $61 \%$, respectively (Fig. 3b). The blockade was only effective in the NTR-positive tissues, which demonstrates that the in vivo uptake for ${ }^{99 \mathrm{~m}}$ Tc-NT-XIX was very specific and due to interaction with NTR. NT-XI $(0.3 \mathrm{mg} /$ mouse $)$ was used to displace ${ }^{99 \mathrm{~m}}$ Tc-NT-XIX since NT(8-13) was not so effective (data not shown). In the in vitro tests, non-specific binding was always tested with NT(8-13) and found to be negligible. In vitro, we used inhibitors of peptidases that prevent metabolism. However, in vivo NT(8-13) is susceptible to rapid enzymatic degradation, which would explain why the inhibition was not statistically significant. NT-XI showed longer plasma half-life than NT(8-13), and it was likely to be more stable in vivo. Therefore, there would be a sufficient amount of peptide able to displace the in vivo binding of ${ }^{99 \mathrm{~m}} \mathrm{Tc}-\mathrm{NT}$-XIX to the NTR-positive tissues.

The biodistribution of ${ }^{188}$ Re-NT-XIX was comparable to that of ${ }^{99 \mathrm{~m}}$ Tc-NT-XIX at all p.i. times (Fig. 3a). Uptake in blood was slightly higher, whereas uptake in receptorpositive tissues was slightly lower. This resulted in slightly lower tumour-to-tissue ratios for ${ }^{188}$ Re-NT-XIX compared to ${ }^{99 \mathrm{~m}}$ Tc-NT-XIX, especially tumour-to-blood ratios.

\section{SPECT/CT imaging}

The tumour xenografts could be perfectly visualised by SPECT/CT imaging with ${ }^{99 \mathrm{~m}}$ Tc-NT-XIX at $1.5 \mathrm{~h}$ p.i. (Fig. 5a). The specificity of the tumour uptake was also demonstrated since no activity was found in the tumour of the animal receiving co-injection of ${ }^{99 \mathrm{~m}} \mathrm{Tc}-\mathrm{NT}$-XIX and unlabelled NT-XI (Fig. 5b). The favourable biodistribution of NT-XIX resulted in much better tumour imaging than with previous analogues $[17,19]$.

\section{Therapy studies}

Tumour volume progressively increased in the control group. The group administered with two i.v. injections of ${ }^{188} \mathrm{Re}-\mathrm{NT}$-XIX $15 \mathrm{MBq} /$ mouse (days 0 and 3) showed a

Table 2 Tumour-to-tissue ratios in nude mice with HT-29 tumour xenografts

\begin{tabular}{|c|c|c|c|c|}
\hline Time (h) & Analogue $^{\mathrm{a}}$ & $\mathrm{Tu} / \mathrm{B} 1$ ratio & $\mathrm{Tu} / \mathrm{Ki}$ ratio & $\mathrm{Tu} / \mathrm{Li}$ ratio \\
\hline \multirow[t]{3}{*}{1.5} & ${ }^{99 \mathrm{~m}} \mathrm{Tc}-\mathrm{NT}-\mathrm{XI}$ & $11.7 \pm 3.9$ & $0.4 \pm 0.1$ & $2.0 \pm 0.6$ \\
\hline & ${ }^{99 m}$ Tc-NT-XII & $12.2 \pm 1.0$ & $0.9 \pm 0.8$ & $0.9 \pm 0.1$ \\
\hline & ${ }^{99 \mathrm{~m}}$ Tc-NT-XIX & $13.1 \pm 4.9$ & $1.7 \pm 0.4 * *$ & $2.3 \pm 0.7^{\S \S}$ \\
\hline \multirow[t]{3}{*}{5} & ${ }^{99 \mathrm{~m}}$ Tc-NT-XI & $20.6 \pm 10.8$ & $0.2 \pm 0.1$ & $1.3 \pm 0.7$ \\
\hline & ${ }^{99 \mathrm{~m}} \mathrm{Tc}-\mathrm{NT}-\mathrm{XII}$ & $21.4 \pm 3.7$ & $0.9 \pm 0.3$ & $2.0 \pm 0.6$ \\
\hline & ${ }^{99 \mathrm{~m}}$ Tc-NT-XIX & $28.1 \pm 2.5$ & $1.9 \pm 0.1 * *, \S \S$ & $4.5 \pm 0.7 * *, \S \S$ \\
\hline \multirow[t]{3}{*}{24} & ${ }^{99 \mathrm{~m}} \mathrm{Tc}-\mathrm{NT}-\mathrm{XI}$ & $69.5 \pm 17.9$ & $0.2 \pm 0.0$ & $2.0 \pm 0.3$ \\
\hline & ${ }^{99 m}$ Tc-NT-XII & $79.6 \pm 19.0$ & $1.2 \pm 0.1$ & $4.6 \pm 0.7$ \\
\hline & ${ }^{99 m}$ Tc-NT-XIX & $118.1 \pm 13.6^{*}$ & $2.6 \pm 0.1 * *, \S \S$ & $8.3 \pm 0.6^{* *}, \S \S$ \\
\hline
\end{tabular}

Data are mean \pm SD of individual ratios $(n=3-7)$.

${ }^{\mathrm{a}}$ Analogues NT-XI and NT-XII previously published, for comparison [18-19]

$\mathrm{Tu}$ tumour, $\mathrm{Bl}$ blood, $\mathrm{Ki}$ kidney, $\mathrm{Li}$ liver

${ }^{*} p<0.01,{ }^{* *} p<0.001$ vs ${ }^{99 \mathrm{~m}}$ Tc-NT-XI, ${ }^{\S} p<0.01,{ }^{\S} p<0.001$ vs ${ }^{99 \mathrm{~m}}$ Tc-NT-XII (one-way ANOVA+Tukey’s post hoc test) 
a

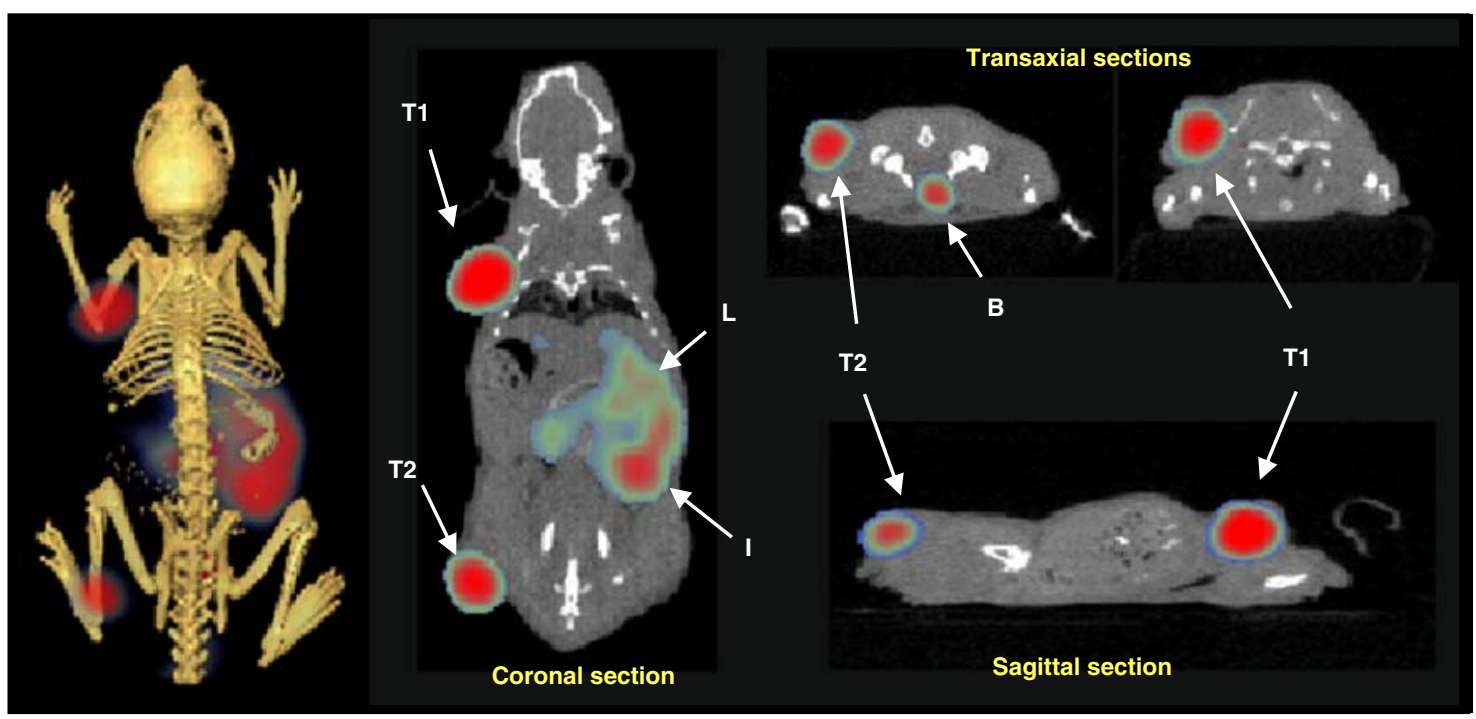

b

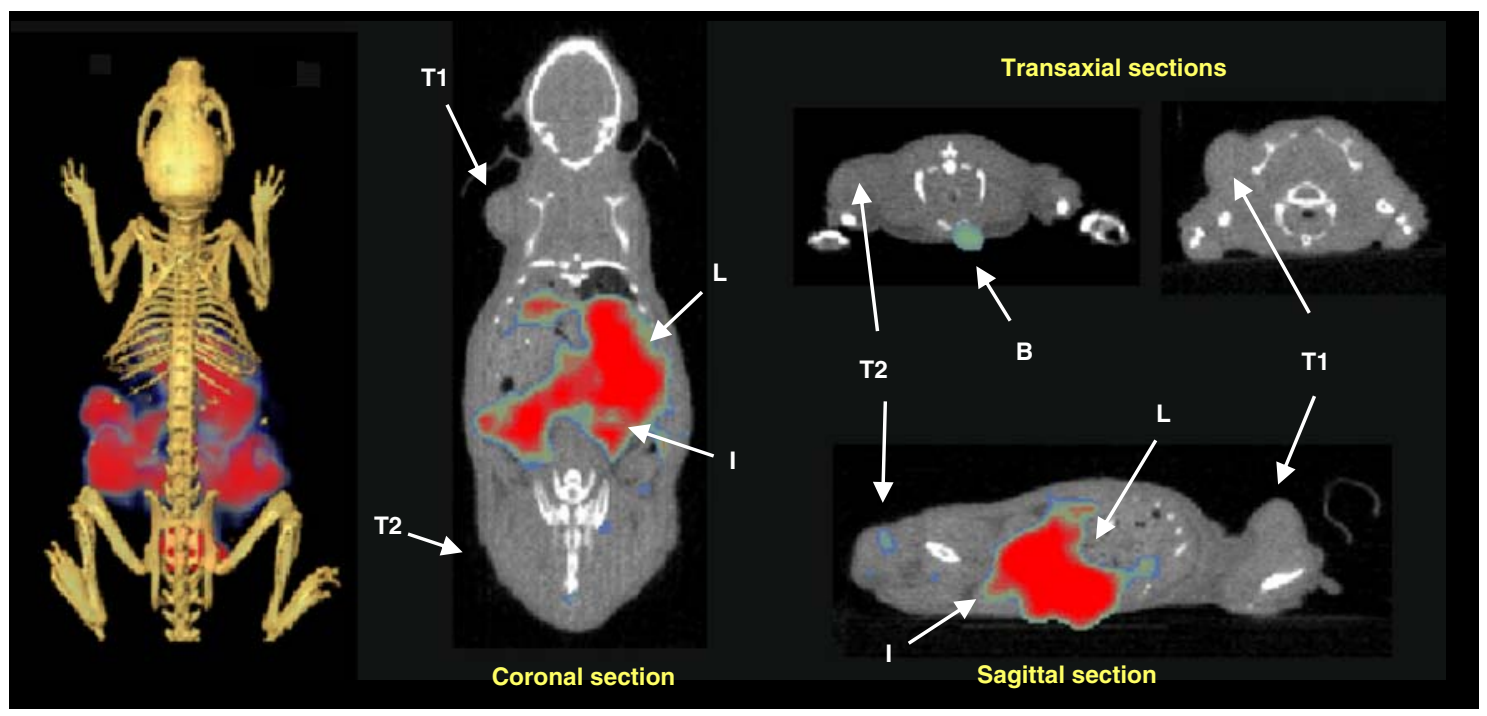

Fig. 5 SPECT/CT images of mice bearing HT-29 tumour xenografts $1.5 \mathrm{~h}$ after i.v. injection of ${ }^{99 \mathrm{~m}} \mathrm{Tc}-\mathrm{NT}-X I X(3.5-4 \mathrm{MBq})$. a Unblocked. b Blocked. Blocked animals received ${ }^{99 \mathrm{~m}} \mathrm{Tc}-\mathrm{NT}$-XIX co-injected with

slower tumour growth in the first week compared to the control. Afterwards, tumour growth was comparable to the control group (Fig. 6a). Inhibition of tumour growth after injection of ${ }^{188}$ Re-NT-XIX, either in three fractions of $10 \mathrm{MBq}$ (days 0,3 and 6) or in four fractions of $7.5 \mathrm{MBq}$ (days $0,3,6$ and 9), was similar. The therapeutic effect of $3 \times 10$ and $4 \times 7.5 \mathrm{MBq}$ was statistically significant in the first 6 days. However, the consistent inhibition in tumour growth observed afterwards in both groups was not significantly different from controls. Tumour growth decrease at the end of the experiment was $55 \%$ and $47 \%$ unlabelled NT-XI [18], $0.3 \mathrm{mg} / \mathrm{mouse} . T 1$ Upper tumour, $T 2$ lower tumour, $L$ liver, $I$ intestines, $B$ bladder

for $3 \times 10$ and $4 \times 7.5 \mathrm{MBq}$, respectively (Fig. 6a). Tumour doubling time also increased from $4.8 \pm 0.5$ days in the control group to $6.3 \pm 1.8$ and $6.0 \pm 1.0$ days in the groups treated with $3 \times 10$ and $4 \times 7.5 \mathrm{MBq}$ of ${ }^{188}$ Re-NT-XIX (Fig. 6b).

\section{Discussion}

Bioactive peptides regulate a large variety of physiological functions and also play a crucial role in pathological 
Fig. 6 Therapeutic effect of ${ }^{188}$ Re-NT-XIX (total accumulated dose $30 \mathrm{MBq} / \mathrm{mouse}$ ) in mice with HT-29 tumour xenografts. a Timecourse tumour growth. Data are expressed as the volume of tumours relative to that in the same animals immediately before the first injection (mean $\pm \mathrm{SD}$ of 4-7 animals). Statistical analysis (one-way ANOVA+Tukey's post hoc test): $p<0.05$ all treated groups vs. control at days 1 and 2 after first injection; $p<0.05$ groups $3 \times 10$ and $4 \times$ $7.5 \mathrm{MBq}$ vs. control at day 6 after first injection. b Comparison of tumour volume and tumour doubling time

conditions such as tumour growth and tumour progression, inflammation, platelet aggregation or apoptosis. These peptides exert their actions through membrane-bound receptors at very low concentrations. Peptide receptors are overexpressed on various cancer cells and represent attractive targets for tumour imaging and therapy. Over-expression of NT receptors has been reported in breast, pancreatic, prostate, lung and colon cancers [3-6]. Peptide-based conjugates consisting of NT analogues linked to radionuclides could be interesting radiopharmaceuticals to selectively deliver radionuclides to receptor-expressing tumour cells. NT-XIX is a new NT(8-13) derivative with modifications at the three cleavage sites (Table 1), which led to a substantial increase in metabolic stability. The higher stability in vivo compared to previous stabilised NT analogues is of special interest since a higher amount of intact peptide would reach the tumour area, increasing the probability of binding to the receptors. Moreover, ${ }^{99 \mathrm{~m}} \mathrm{Tc}-\mathrm{NT}$-XIX retained affinity for NTR1 in the nanomolar range (Table 1), it was rapidly internalised into HT-29 cells after binding and more than half of the internalised radioactivity was still trapped inside the cells after $24 \mathrm{~h}$ (Fig. 2a), which is important since retention of radioactivity in the tumour is essential for the therapeutic efficacy of a radiopharmaceutical.

The interest of this new NT analogue was confirmed in vivo in nude mice with HT-29 xenografts. The highest uptake was found in the tumour, whereas kidney uptake and liver uptake were 1.6 and 2.0 times lower, respectively (Fig. 3a). High kidney accumulation is a widely reported problem with radiolabelled neuropeptide analogues [23, 26-29], and, therefore, the low kidney uptake observed for ${ }^{99 \mathrm{~m}} \mathrm{Tc}-\mathrm{NT}$-XIX even at an early time point is an interesting feature (Fig 4). In vivo uptake of ${ }^{99 \mathrm{~m}}$ Tc-NT-XIX was due to specific interaction with NTR, as demonstrated in blockade experiments (Fig. 3b), in which the uptake in the tumour and in the gastrointestinal tract, receptor-positive tissue [3] was significantly inhibited. In contrast to the rapid radioactivity clearance from most organs in the first $24 \mathrm{~h}$ p.i., the activity was retained longer in the tumour (Fig. 3a), which matches the results of the in vitro externalisation studies. Interestingly, ${ }^{99 \mathrm{~m}} \mathrm{Tc}-\mathrm{NT}$-XIX showed the best tumour-to-kidney ratios obtained with an NT analogue, radiolabelled with either ${ }^{99 \mathrm{~m}} \mathrm{Tc}[20-22,26,34]$ or with ${ }^{111} \mathrm{In}$ $[30,31]$. The tumours were clearly delineated by SPECT/

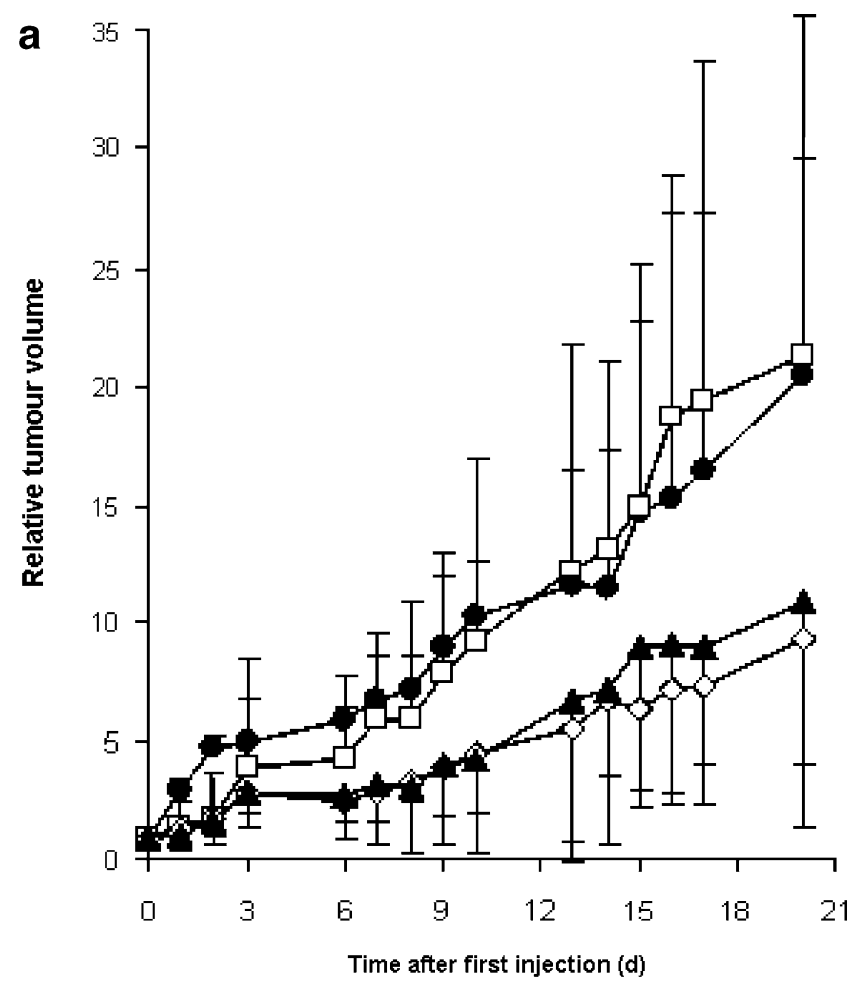

$\rightarrow-$ Control $\square-2 \times 15 \mathrm{MBq}-\mathbf{0}-3 \times 10 \mathrm{MBq}-4 \times 7.5 \mathrm{MBq}$

b

Mean value (days)

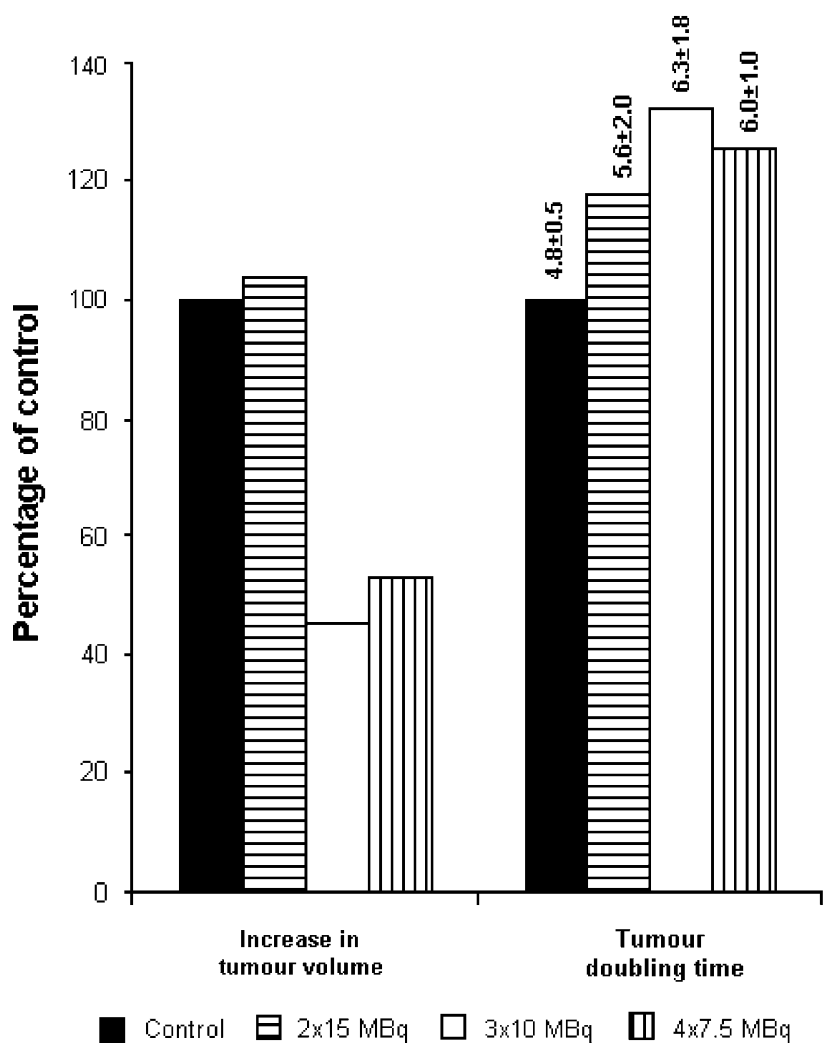


CT (Fig. 5a). A higher accumulation was found in tumour than in any other tissue, which corroborates the results obtained in the biodistribution studies. The specificity of the tumour uptake was also demonstrated by SPECT/CT (Fig. 5b). SPECT/CT imaging with ${ }^{99 \mathrm{~m}}$ Tc-NT-XIX was superior to that with the best doubly stabilised analogue ${ }^{99 \mathrm{~m}}$ Tc-NT-XII [19] and would confirm its clear potential for future application as a diagnostic radiopharmaceutical.

NT-XIX showed a comparable biodistribution radiolabelled with ${ }^{99 \mathrm{~m}} \mathrm{Tc}$ and ${ }^{188} \mathrm{Re}$ (Fig. 3a). In preliminary therapeutic studies, ${ }^{188}$ Re-NT-XIX (total dose of $30 \mathrm{MBq} /$ mouse) was able to significantly inhibit the growth of HT-29 tumour xenografts in nude mice. ${ }^{188}$ Re-NT-XIX, injected either in three or in four fractionated doses, reduced tumour growth by $50 \%$ (Fig. 6), suggesting that ${ }^{188}$ Re-NT-XIX holds the potential to be used as a radiotherapeutic agent.

The results reported here demonstrate that stability plays a very important role in the tumour uptake of radiolabelled NT analogues. Despite a slight decrease in receptor affinity and a lower rate of internalisation, in vivo tumour uptake (Fig. 4) was similar to that of ${ }^{99 \mathrm{~m}}$ Tc-NT-XII [19] and higher to that of ${ }^{99 \mathrm{~m}}$ Tc-NT-VIII or ${ }^{99 \mathrm{~m}} \mathrm{Tc}-\mathrm{NT}-\mathrm{XI}$ [18], and this is likely due to the longer in vivo stability. Other interesting findings were the low kidney and liver uptakes obtained for this derivative (Figs. 3a and 4). The persistent accumulation of radiolabelled peptides in normal tissues could compromise their potential use as therapeutic agents due to possible radiation toxicity. It is well known that the kidneys are a major site in the catabolism of low molecular weight molecules. However, radiometal-chelated amino acids are not rapidly excreted since they bind to intracellular metalbinding proteins and remain trapped. High kidney uptake may result in renal toxicity [31] and, therefore, have a negative impact on the potential therapeutic efficacy of a peptide radiopharmaceutical. Different methods have been tried to reduce kidney uptake such as administration of basic, cationic amino acids (L-lysine and arginine) or infusion of low doses of a gelatin-based plasma expander [32-34]. In the case of radiolabelled NT analogues that can bind to intestinal NT receptors, the intestine may also be an important dose-limiting organ. In contrast to the kidneys, the intestine is an organ with a rapid cell turnover and symptoms of intestinal radiation toxicity appear early, during or shortly after radiation therapy. Acute radiation enteropathy results in mucosal inflammation and is often self-limiting and reversible. Less frequent, chronic bowel toxicity may occur later and is characterised by progressive intestinal wall fibrosis and vascular sclerosis. Different approaches have been evaluated to protect the intestine against radiation toxicity such as interleukin-11, immunomodulators, inhibitors of proteinase-activated receptors, inhibitors of thrombin and statins [35-39]. Prophylaxis with antioxidant and radioprotectant agents such as amifostine may also be considered to limit possible radiation damage in normal tissues [40]. In the therapy studies with ${ }^{188} \mathrm{Re}$ NT-XIX, an inhibition of tumour growth was obtained after injection of three or four fractions. The possibility of using fractionated doses would reduce injury in most normal tissues. Moreover, radioactivity was cleared more rapidly from healthy organs than from tumour, and, therefore, the risk of radiation toxicity in normal tissues with this analogue would also be lower.

\section{Conclusion}

In the present study, a new stabilised NT analogue is introduced. Its high stability was accompanied by a high tumour uptake and lower kidney uptake, which led to tumourto-kidney ratios much better than those found for other derivatives already reported. The clear visualisation of tumours by SPECT/CT with NT-XIX labelled with the $\gamma$ emitting radionuclide ${ }^{99 \mathrm{~m}} \mathrm{Tc}$, together with the promising results in preliminary therapeutic studies (labelled with the $\beta$-radionuclide ${ }^{188} \mathrm{Re}$ ), justifies the interest in such a peptide. Therefore, we conclude that the new analogue is an excellent candidate for future application in imaging and therapy of NTR-positive tumours. Clinical studies will help to determine the potential utility of NT-XIX in human oncology.

Acknowledgements We thank the Fund for Scientific ResearchFlanders Belgium (contract No. G.0036.04) for financial support, Ms. Harriet Struthers for her assistance with editing the manuscript and Ms. Margaretha Lutz for her technical help.

\section{References}

1. Reubi JC, Schär JC, Waser B, Wenger S, Heppeler A, Schmitt JS, et al. Affinity profiles for human somatostatin receptor subtypes SST1-SST5 of somatostatin radiotracers selected for scintigraphic and radiotherapeutic use. Eur J Nucl Med. 2000;27:273-82.

2. Anderson CJ, Dehdashti F, Cutler D, Schwarz SW, Laforest R, Bass LA, et al. ${ }^{64} \mathrm{Cu}$-TETA-Octreotide as PET imaging agent for patients with neuroendocrine tumors. J Nucl Med. 2001;42: 213-21.

3. Evers BM. Neurotensin and growth in normal and neoplastic tissues. Peptides. 2006;27:2424-33.

4. Carraway RE, Plona AM. Involvement of neurotensin in cancer growth: evidence, mechanisms and development of diagnostic tools. Peptides. 2006;27:2445-60.

5. Carraway RE, Leeman SE. The isolation of a new hypotensive peptide, neurotensin, from bovine hypothalami. J Biol Chem. 1973;248:6854-61.

6. Nemeroff CB, Luttinger D, Prange AJJ. Neurotensin: central nervous system effects of a neuropeptide. Trends Neurosc. 1980;3:212-5.

7. Kitabgi P. Effects of neurotensin on intestinal smooth muscle: application to the study of structure-activity relationships. Ann NY Acad Sci. 1982;400:37-55.

8. Vincent JP, Mazella P, Kitabgi P. Neurotensin and neurotensin receptors. Trends Pharmacol Sci. 1999;20:302-9. 
9. Mazella J, Zsürger N, Navarro V, Chabry J, Kaghad M, Caput D, et al. The $100-\mathrm{kDa}$ neurotensin receptor is gp95/sortilin, a non-Gprotein-coupled receptor. J Biol Chem. 1998;273:26273-6.

10. Morinville A, Martin S, Lavallée M, Vincent JP, Beaudet A, Mazella J. Internalization and trafficking of neurotensin via NTS3 receptors in HT29 cells. Int J Biochem Cell Biol. 2004;36:2153-68.

11. Reubi JC, Waser B, Friess H, Büchler M, Laissue J. Neurotensin receptors: a new marker for human ductal pancreatic adenocarcinoma. Gut. 1998;42:546-50.

12. Ehlers RA, Kim S, Zhang Y, Ethridge RT, Murrilo C, Hellmich $\mathrm{MR}$, et al. Gut peptide receptor expression in human pancreatic cancers. Ann Surg. 2000;231:838-48.

13. Souazé F, Dupouy S, Viardot-Foucault V, Bruyneel E, Attaub S, Gespach C, et al. Expression of neurotensin and NT1 receptor in human breast cancer: a potential role in tumor progression. Cancer Res. 2006;66:6243-9.

14. Jemal A, Murray T, Ward E, Samuels A, Tiwari RC, Ghafoor A, et al. Cancer statistics, 2005. CA Cancer J Clin. 2005;55:10-30.

15. American Cancer Society. Breast cancer facts \& figures 20052006. Atlanta: American Cancer Society Inc.

16. Kitabgi P, De Nadai F, Rovère C, Bidard JN. Biosynthesis, maturation, release and degradation of neurotensin and neuromedin N. Ann NY Acad Sci. 1992;668:30-42.

17. Garcia-Garayoa E, Blaeuenstein P, Bruehlmeier M, Blanc A, Iterbeke $\mathrm{K}$, Conrath $\mathrm{P}$, et al. Preclinical evaluation of a new, stabilized neurotensin(8-13) pseudopeptide radiolabeled with ${ }^{99 m}$ Tc. J Nucl Med. 2002;43:374-83.

18. Bruehlmeier M, Garcia Garayoa E, Blanc A, Holzer B, Gergely S, Tourwé D, et al. Stabilization of neurotensin analogues: effect on peptide catabolism, biodistribution and tumor binding. Nucl Med Biol. 2002;29:321-7.

19. García Garayoa E, Maes V, Bläuenstein P, Blanc A, Hohn A, Tourwé D, et al. Double-stabilized neurotensin analogues as potential radiopharmaceuticals for NT receptor-positive tumors. Nucl Med Biol. 2006;33:495-503.

20. Buchegger F, Bonvin F, Kosinski M, Schaffland AO, Prior J, Reubi JC, et al. Radiolabeled neurotensin analog, ${ }^{99 \mathrm{~m}} \mathrm{Tc}-\mathrm{NT}-\mathrm{XI}$, evaluated in ductal pancreatic adenocarcinoma patients. J Nucl Med. 2003;44:1649-54.

21. Maes V, García Garayoa E, Bläuenstein P, Tourwé DA. Novel ${ }^{99 \mathrm{~m}} \mathrm{Tc}$-labelled neurotensin analogs with optimized biodistribution properties. J Med Chem. 2006;49:1833-6.

22. Schibli R, La Bella R, Alberto R, Garcia Garayoa E, Ortner K, Abram $U$, et al. Influence of the denticity of ligand systems on the in vitro and in vivo behavior of ${ }^{99 \mathrm{~m}} \mathrm{Tc}(\mathrm{I})$-tricarbonyl complexes: a hint for the future functionalization of biomolecules. Bioconjugate Chem. 2000;11:345-51.

23. García Garayoa E, Allemann-Tannahill L, Bläuenstein P, Willmann $\mathrm{M}$, Carrel-Rémy N, Tourwé $\mathrm{D}$, et al. In vitro and in vivo evaluation of new radiolabeled neurotensin(8-13) analogues with high affinity for NT1 receptors. Nucl Med Biol. 2001;28:75-84.

24. Vita N, Laurent P, Lefort S, Chalon P, Dumont X, Kaghad M, et al. Cloning and expression of a complementary DNA encoding a high affinity human neurotensin receptor. FEBS Lett. 1993;317:139-42.

25. Mazella J, Vincent JP. Internalization and recycling properties of neurotensin receptors. Peptides. 2006;27:2488-92.
26. de Visser M, Janssen PJJM, Srinivasan A, Reubi JC, Waser B, Erion JL, et al. Stabilised ${ }^{111}$ In-labelled DTPA- and DOTAconjugated neurotensin analogues for imaging and therapy of exocrine pancreatic cancer. Eur $\mathrm{J}$ Nucl Med Mol Imaging. 2003;30:1134-9.

27. Achilefu S, Srinivasan A, Schmidt MA, Jimenez HN, Bugaj JE, Erion JL. Novel bioactive and stable neurotensin peptide analogues capable of delivering radiopharmaceuticals and molecular beacons to tumors. J Med Chem. 2003;46:3403-11.

28. Behr TM, Jenner N, Béhé M, Angerstein C, Gratz S, Raue F, et al. Radiolabeled peptides for targeting cholecystokinin-B/ gastrin receptor-expressing tumors. J Nucl Med. 1999;40: $1029-44$.

29. Boerman OC, Oyen WJG, Corstens FHM. Between the Scylla and Charybdis of peptide radionuclide therapy: hitting the tumor and saving the kidney. Eur J Nucl Med. 2001;28:1447-9.

30. Zhang K, An R, Gao Z, Zhang Y, Aruva MR. Radionuclide imaging of small-cell lung cancer (SCLC) using 99mTc-labeled neurotensin peptide 8-13. Nucl Med Biol. 2006;28:505-12.

31. Lambert B, Cybulla M, Weiner SM, Van de Wiele C, Ham H, Dierckx RA, et al. Renal toxicity after radionuclide therapy. Radiat Res. 2004;161:607-11.

32. Behr TM, Goldenberg DM, Becker W. Reducing the renal uptake of radiolabelled antibody fragments, and peptides for diagnosis and therapy: present status, future prospects and limitations. Eur J Nucl Med. 1998;25:201-12.

33. Rolleman EJ, Valkema R, de Jong M, Kooij PP, Krenning EP. Safe and effective inhibition of renal uptake of radiolabelled octreotide by a combination of lysine and arginine. Eur J Nucl Med Mol Imag. 2003;30:9-15.

34. Vegt E, Wetzels JFM, Russel FGM, Masereeuw R, Boerman OC, van Eerd JE, et al. Renal uptake of radiolabeled octreotide in human subjects is efficiently inhibited by succinylated gelatin. J Nucl Med. 2006;47:432-6.

35. Boerma M, Wang J, Burnett AF, Santin AD, Roman JJ, HauerJensen M. Local administration of interleukin-11 ameliorates intestinal radiation injury in rats. Cancer Res. 2007;67:9501-6.

36. Boerma M, Wang J, Richter KK, Hauer-Jensen M. Orazipone, a locally acting immunomodulator, ameliorates intestinal radiation injury: a preclinical study in a novel rat model. Int J Radiat Oncol Biol Phys. 2006;66:552-9.

37. Wang J, Hauer-Jensen M. Radiation toxicity and proteinaseactivated receptors. Drug Dev Res. 2003;60:1-8.

38. Wang J, Zheng H, Ou X, Albertson CM, Fink LM, Herbert JM, et al. Hirudin ameliorates intestinal radiation toxicity in the rat: support for thrombin inhibition as strategy to minimize sideeffects after radiation therapy and as countermeasure against radiation exposure. J Thromb Haemostasis. 2004;2:2027-35.

39. Wang J, Boerma M, Fu Q, Kulkarni A, Fink LM, Hauer-Jensen M. Simvastatin ameliorates radiation enteropathy development after localized, fractionated irradiation by a protein C-independent mechanism. Int J Radiat Oncol Biol Phys. 2007;68:148390.

40. Kouvaris JR, Kouloulias VE, Vlahos LJ. Amifostine: the first selective-target and broad-spectrum radioprotector. Oncologist. 2007;12:738-47. 